\title{
POST-LAMINECTOMY DEFORMITIES
}

\author{
DEFORMIDADES PÓS-LAMINECTOMIA
}

DEFORMIDADES POST-LAMINECTOMÍA

Fabiano Stumpf Lutz' ${ }^{1}$ Luis Eduardo Munhoz da Rocha ${ }^{1}$

\begin{abstract}
Objective: To present the deformities and evaluate the results of their treatment. Methods: Retrospective study of patients with deformity following surgical access to the spinal canal. Fifteen patients who met the inclusion criteria were included. Patients without complete data in medical records were excluded. Results: Fourteen patients underwent surgical treatment and one patient received conservative treatment with vest type TLSO. The average angle of kyphosis correction was $87^{\circ}$ preoperatively to $38^{\circ}$ postoperatively, while the associated scoliosis correction was $69^{\circ}$ preoperatively to $23^{\circ}$ postoperatively. Conclusions: The prevention of deformity should be emphasized to avoid laminectomy alone, while laminoplasty should be the procedure of choice for canal access in surgeries where there is no need for resection of the posterior elements.
\end{abstract}

Keywords: Kyphosis; Laminectomy; Paraplegia; Child, Congenital abnormalities; Arthrodesis.

\section{RESUMO}

Objetivos: Apresentar as deformidades e avaliar os resultados de seu tratamento. Métodos: Estudo retrospectivo de pacientes portadores de deformidade após cirurgia de acesso ao canal vertebral. Incluíram-se quinze pacientes que satisfaziam os critérios de inclusão. Foram excluídos os pacientes que não apresentavam dados completos no prontuário. Resultados: Quatorze pacientes foram submetidos a tratamento cirúrgico e um paciente ao tratamento conservador com colete do tipo OTLS. A correção angular média da cifose foi de $87^{\circ}$ no pré-operatório para $38^{\circ}$ após a cirurgia, enquanto a correção da escoliose associada foi de $69^{\circ}$ no pré-operatório para $23^{\circ}$ no pós-operatório. Conclusões: A prevenção da deformidade deve ser enfatizada evitando-se a laminectomia isolada, enquanto a laminoplastia deve ser o procedimento de escolha para acesso ao canal nas cirurgias em que não há necessidade de ressecção dos elementos posteriores.

Descritores: Cifose; Laminectomia; Paraplegia; Criança; Anormalidades congênitas; Artrodese.

\section{RESUMEN}

Objetivo: Presentar las deformidades y evaluar los resultados de su tratamiento. Métodos: Estudio retrospectivo de los pacientes con deformidad después del acceso quirúrgico al canal espinal. Quince pacientes que cumplían los criterios de inclusión fueron incluidos. Se excluyeron los pacientes que no tenían dados completos en la historia clínica. Resultados: Catorce pacientes fueron sometidos a tratamiento quirúrgico y un paciente recibió tratamiento conservador con ortesis OTLS. La corrección de la cifosis angular promedio fue de $87^{\circ}$ antes de la operación a $38^{\circ}$ después de la cirugía, mientras que la escoliosis asociada fue de $69^{\circ}$ antes de la operación a $23^{\circ}$ después de la operación. Conclusiones: La prevención de la deformidad debe ser destacada para evitar laminectomía solo, mientras que laminoplastia debe ser el procedimiento de elección para el acceso al canal durante la cirugía donde no hay necesidad de resección de los elementos posteriores.

Descriptores: Cifosis; Laminectomía; Paraplejía; Niño; Anomalías congénitas; Artrodesis.

\section{INTRODUCTION}

Spinal deformities following surgical procedures for access to the medullary canal, such as laminectomy or laminoplasty, occur in children submitted to this surgery.

Tachdjian and Matson ${ }^{1}$ reported the appearance of spinal deformity in $26 \%$ of newborn infants and children who underwent laminectomy. Other authors have reported an incidence of $90-100 \%{ }^{2}$

Laminectomies are usually performed for the treatment of spinal cord tumors, neurofibromatosis and syringomyelia, among other intracanal pathologies.

According to Lonstein, ${ }^{3}$ it is proposed that following laminectomy, there is increased pressure on the cartilage endplates of the vertebral bodies in the anterior direction. Over time, cartilage growth is decreased and there is vertebral wedging, leading mainly to kyphosis, but with the potential to evolve into other spinal deformities.
If a post-laminectomy deformity develops, it may evolve into a serious and incapacitating deformity, threatening the spinal cord function. The relationship between neurological deficit and spinal deformities is complex. If a deficit occurs or deteriorates, it may be a result of spinal cord compression at the level of the deformity, or of the recurrence of a tumor. ${ }^{4}$

The treatment of post-laminectomy deformities is essentially surgical, provided above-normal values are present and the deformity proves to be progressive.

The type of surgical treatment used is closely related to the biomechanical and pathomorphological characteristics of the deformity, and also to the presence of compression of the nerve structures.

The goal of this study is to present our strategy and the results of the surgical and conservative treatment of deformities following surgical access to the spinal canal in children.

1. Hospital Pequeno Príncipe and Hospital de Clínicas do Paraná, Curitiba, PR, Brazil.

Study conducted at the Orthopedics and Traumatology Service of the Hospital Pequeno Príncipe, Curitiba, PR, Brazil.

Correspondence: Av. Governador Irineu Bornhausen 3440/902. Agronômica. Florianópolis, SC, Brasil. 88025-200. fslutz@ hotmail.com 


\section{MATERIALS AND METHODS}

A retrospective study based on a review of the medical records of patients treated by the Orthopedics Service of Hospital Pequeno Príncipe, in Curitiba, Paraná, Brazil, for deformity following surgical access to the spinal canal, between 2000 and 2012. The study was approved by the Research Ethics Committee of the abovementioned hospital.

Fifteen treated patients were found in this period. The inclusion criterion used was the period described above and the diagnosis of deformity following surgical access to the spinal canal. The exclusion criterion used was medical records with incomplete data. All fifteen patients were included in the study.

Fourteen of these patients were treated surgically and one was treated conservatively with the use of a TLSO type vest.

Ten patients were submitted to laminectomy, and four other patients to laminoplasty. (Table 1)

Thirteen patients underwent surgical access to the canal due to malignant tumors.

In relation to the underlying disease, five patients had a diagnosis of neuroblastoma, four a diagnosis of astrocytoma, one a diagnosis of teratoma, one a diagnosis of PNET, one had had a diastematomyelia correction and three a diagnosis of glioma.

The average age at laminectomy/laminoplasty was three years and one month.

Five patients presented with neurological deficit prior to the treatment of the acquired deformity, which ranged from clonus to paraplegia. (Table 2)

The average age at the time of surgery for correction of the deformity was eleven years and seven months.

Three patients were treated with double access, with combined anterior and posterior fusion. Eleven patients underwent surgery via the posterior route only. Anterior instrumentation was not used in any of the cases. Posterior instrumentation was used in the fourteen cases treated surgically.

Table 1. Diagnosis.

\begin{tabular}{c|c}
\hline Diagnosis & Patients \\
\hline Neuroblastoma & 5 \\
\hline Astrocytoma & 4 \\
\hline Glioma & 3 \\
\hline PNET & 1 \\
\hline Teratoma & 1 \\
\hline Diastematomyelia & 1 \\
\hline Total & 15 \\
\hline
\end{tabular}

Table 2. Deformity and neurological deficit.

\begin{tabular}{c|c|c}
\hline Patient & Deformity & Neurological deficit \\
\hline 1 & Kyphosis & Force M4 L3 right \\
\hline 2 & Lordoscoliosis & No \\
\hline 3 & Scoliosis & No \\
\hline 4 & Kyphosis & Paraplegia \\
\hline 5 & Kyphosis & No \\
\hline 6 & Kyphoscoliosis & No \\
\hline 7 & Kyphoscoliosis & No \\
\hline 8 & Lordoscoliosis & No in both LL \\
\hline 9 & Kyphosis & No \\
\hline 10 & Kyphoscoliosis & Clonus LL \\
\hline 11 & Kyphoscoliosis & No \\
\hline 12 & Kyphoscoliosis & No \\
\hline 13 & Kyphosis & No \\
\hline 14 & Kyphoscoliosis &
\end{tabular}

The mean follow-up period was three years and eight months (ranging from eight months to eleven years and three months) after surgical correction.

The magnitudes of the curves were measured using the Cobb method and the mean values are presented with standard deviation. The statistical analyses were performed using the Student's t-test. Statistical significance was established at the level of $p<0.05$.

\section{RESULTS}

In general, the spinal deformities were detected within four years and three months after laminectomy/laminoplasty.

Ten patients were submitted to laminectomy and four to laminoplasty, totaling fourteen patients treated surgically.

Of the twelve patients treated surgically with kyphosis, the magnitude decreased from $87^{\circ}\left(\mathrm{SD} 23.4^{\circ}\right)$ to $38^{\circ}\left(\mathrm{SD} 21.1^{\circ}\right)(p=0.00)$ after surgery.

In the deformities in which there was associated scoliosis, the preoperative mean value was $69^{\circ}\left(\mathrm{SD} 19.4^{\circ}\right)$, which decreased to $23^{\circ}($ SD 20.2 $)(p=0.00)$.

The patient treated conservatively is still in follow-up and their scoliosis is currently at $18^{\circ}$ of T3-T10 and $26^{\circ}$ of T10-L4, having already reached skeletal maturity.

Of the fourteen patients treated surgically, five presented with neurological deficit prior to the correction of the deformity. Following the surgery for correction, two achieved complete resolution of the neurological symptoms and the others did not result in deterioration. The only patient treated conservatively did not present any changes in their neurological status throughout the follow-up period. (Table 2)

\section{DISCUSSION}

Post-laminectomy deformity is the clinical and radiographic expression of the loss of resistance of the posterior elements to traction forces, associated or not with failure of capacity to support the anterior portion of the spinal column, resulting in progressive deformity, sometimes accompanied by neurological deficit due to compression of the nerve tissues inside the spinal canal.

According to Robert and Bortolussi, ${ }^{4}$ as the kyphosis progresses, the weight bearing axis of the body is anteriorly displaced, increasing the tendency towards kyphosis progression and forming a vicious circle that can only be interrupted with the restoration of the sagittal balance of the spine.

An understanding of the concept of sagittal balance of the spine and of the biomechanical aspects present in this type of deformity is crucial in the elaboration of its treatment. This treatment should take into account factors such as magnitude and speed of progression, as well as neurological alterations.

Post-laminectomy deformities appear relatively early (in this series, four years and three months after laminectomy), but patients should be followed up until the end of adolescence, as deformities can arise and/or deteriorate rapidly during puberty.

Postoperative immobilization does not prevent the appearance of the deformity but can delay it. According to Dubousset et al., ${ }^{2}$ all children should be treated with post-laminectomy immobilization.

Laminoplasty can also be a solution if there is no need for complete resection of the posterior elements (e.g. in a tumor that does not affect them), but a necessary condition for success is postoperative immobilization, as mentioned by Papagelopoulus et al. ${ }^{5}$

In the vast majority of cases, the patient needs surgical treatment. According to Stagnara, ${ }^{6}$ there are indications for the production of a preoperative distraction plaster cast, and it would help to correct the deformity, increase pulmonary capacity and allow better surgical correction, yet in this series it was not used on any patient.

Of the patients with neurological damage before the correction, if the installation is acute there is a better chance of recovery when the canal is decompressed. Nevertheless, in those where the neurological deficit is chronic, the chances of improvement are drastically reduced. ${ }^{7}$ In the series, of the five patients with pre-correction neuro- 
logical deficit, two achieved complete resolution of the injury and the other three did not experience worsening of the neurological status.

Although there is plenty of data in the literature addressing iatrogenic deformities of the spine, most of this data is restricted to the cervical column.

In the study by Otsuka et al., ${ }^{8} 12$ patients were treated surgically, and mean kyphosis was corrected from $84^{\circ}$ to $35^{\circ}$, similar to our series.

The development of new fixation systems has enabled a more premature and effective approach to the deformity, with improvement of the correction potential.

The approach via a single posterior route has been the route of choice, but as there is extensive variability of clinical presentations, there is no standardization for the treatment. ${ }^{9}$

It is known that the anterior route increases the rate of consolidation, besides reducing correction loss, but the percentage of complications decreases when the surgeon decides not to perform thoracotomy.

Having undergone laminectomy/laminoplasty, children should be carefully observed, as the odds of developing spinal deformities are high.

Orthopedic treatment is indicated as soon as the deformity arises.

The aim of nonsurgical treatment is to delay the progression of the deformity and thereby postpone the arthrodesis until acceptable spinal and pulmonary development.

Both the posterior route and the combined route constitute a viable option for treatment, and their choice will depend on the "personality" of the deformity.

\section{CONCLUSION}

The prevention of the deformity is vitally important. Isolated laminectomy should be avoided whenever possible, while laminoplasty should be the procedure of choice to explore the spinal canal.

All authors declare no potential conflict of interest concerning this article.

\section{REFERENCES}

1. Tachdjian MO, Matson DD. Orthopaedic aspects of intraspinal tumors in infants and children. J Bone Joint Surg Am. 1965;47:223-48.

2. Dubousset J, Guillaumat M, Mechin JF. Retentissement rachidien des laminectomies chez l'enfant. In: Rougerie J, editor. Compressions médullaires non traumatiques de I'enfant. Paris: Masson; 1973. p. 185-93.

3. Lonstein JE. Post-laminectomy kyphosis. Clin Orthop Relat Res. 1977;(128):93-100.

4. Robert $\mathrm{H}$, Bortolussi $\mathrm{C}$. In vitro evolution of the pressure and the geometry of the lumbar disc as a function of the stability of the spine. J Biophys Med Nucl. 1984:8:243-9.

5. Papagelopoulos PJ, Peterson HA, Ebersold MJ, Emmanuel PR, Choudhury SN, Quast LM. Spinal column deformity and instability after lumbar or thoracolumbar lami-

nectomy for intraspinal tumors in children and young adults. Spine (Phila Pa 1976). 1997;22(4):442-51.

6. Stagnara P. Les déformations du rachis. In: Scolioses, cyphoses, lordoses. Paris: Masson; 1985. p. 199-252.

7. Raimondi AJ, Gutierrez FA, Di Rocco C. Laminotomy and total reconstruction of the posterior spinal arch for spinal canal surgery in childhood. J Neurosurg. 1976;45(5):555-60.

8. Otsuka NY, Hey L, Hall JE. Postlaminectomy and postirradiation kyphosis in children and adolescents. Clin Orthop Relat Res. 1998:(354):189-94.

9. Herman JM, Sonntag VK. Cervical corpectomy and plate fixation for postlaminectomy kyphosis. J Neurosurg. 1994;80(6):963-70. 